\title{
PCR-based approach for qualitative molecular analysis of six neurotropic pathogens
}

\author{
R. FERESE ${ }^{1}$, L. SCORZOLINI ${ }^{1,2}$, R. CAMPOPIANO ${ }^{1}$, V. ALBANO ${ }^{1}$, A. M. GRIGUOLI ${ }^{1}$, E. GIARDINA ${ }^{3,4}$, S. SCALA $^{1}$, \\ L. RYSKALIN ${ }^{5}$, C. D'ALESSIO ${ }^{1}$, S. ZAMPATTI ${ }^{1,3}$, R. FANTOZZI ${ }^{1}$, M. STORTO ${ }^{1}$, F. FORNAI ${ }^{1,5}$, S. GAMBARDELLA $^{1}$
}

\begin{abstract}
${ }^{1}$ IRCCS Neuromed, Località Camerelle, 86077, Pozzilli (IS), Italy; ${ }^{2}$ Infectious Disease Unit, Department Public Health and Infectious Disease, "Sapienza" University of Rome, Italy; ${ }^{3}$ Molecular Genetics Laboratory UILDM, Santa Lucia Foundation, Rome, Italy; ${ }^{4}$ Department of Biomedicine and Prevention, School of Medicine, University of Rome 'Tor Vergata', Rome, Italy; ${ }^{5}$ Department of Translational Research and New Technologies in Medicine and Surgery, University of Pisa, Pisa, Italy
\end{abstract}

\begin{abstract}
Summary. - In the last few years, polymerase chain reaction analysis is frequently required to improve the detection of pathogen infections in central nervous system as a potential cause of neurological disorders and neuropsychiatric symptoms. The goal of this paper is to set up a fast, cheap and reliable molecular approach for qualitative detection of six neurotropic pathogens. A method based on PCR has been designed and implemented to guarantee the qualitative DNA detection of herpes simplex virus types 1 and 2 (HSVI/II), Epstein-Barr virus (EBV), cytomegalovirus (CMV), varicella-zoster virus (VZV), rubella virus (RUBV) and Toxoplasma gondii in the cerebrospinal fluid, where otherwise they are barely detectable. Each PCR assay was tested using dilutions of positive controls, which demonstrated a sensitivity allowing to detect up to $10^{2}$ copies/ml in PCR and 10 copies/ $\mathrm{ml}$ in real-time PCR for each pathogen. Once been set up, the protocol was applied to evaluate the cerebrospinal fluid from 100 patients with suspected infectious diseases of the central nervous system and 50 patients without any infection. The method allowed to identify 17 positive cerebrospinal fluid with polymerase chain reaction and 22 with real-time PCR (RT-PCR), respectively. Therefore, application of RT PCR allows a fast and sensitive evaluation of neurotropic DNA pathogens in the course of diagnostic routine within neurological units.
\end{abstract}

Keywords: central nervous system; neurotropic infections; PCR; real-time PCR

\section{Introduction}

A wide range of viruses, including herpes simplex virus types 1 and 2 (HSV I/II), cytomegalovirus (CMV), varicellazoster virus (VZV), Epstein-Barr virus (EBV), human herpes virus 6 (HHV-6), the enterovirus group (echoviruses, polioviruses, coxsackieviruses), adenoviruses, John Cunningham (JC) and BK viruses, arenaviruses, paramyxoviruses, rabies and arboviruses, are associated with neurological diseases of

E-mail: ferese.rosangela@gmail.com; phone: +390865915209. Abbreviations: $\mathrm{CMV}=$ cytomegalovirus; $\mathrm{CNS}=$ central nervous system; $\mathrm{CSF}=$ cerebrospinal fluid; $\mathrm{EBV}=$ Epstein-Barr virus; HSV I/II = herpes simplex virus types 1 and $2 ; \mathrm{HV}=$ herpes virus; JC = John Cunningham; RT-PCR = real-time PCR; RUBV = rubella virus; $\mathrm{TGR}=$ Toxoplasma gondii VZV = varicella-zoster virus the central nervous system (CNS). The identification of these pathogens, especially within cerebrospinal fluid (CSF), is crucial for establishing specific therapy of patients affected by neurological and neuropsychiatric symptoms. For instance, detection of acute EBV infection in the CNS is critical due to its association with meningoencephalitis and CNS lymphomas (CNSLs). This is significant since complications from EBV infections range from 1 up to $18 \%$ of patients with infectious mononucleosis and include encephalitis, meningitis, cerebellitis, polyradiculomyelitis, transverse myelitis, cranial and peripheral neuropathies and psychiatric abnormalities (Connelly and Witt, 1994).

In the last few years, PCR is considered as a valuable tool for identifying pathogen DNA within CSF. In fact, this technique is based on the exponential amplification of a template DNA, which allows to detect a pathogen-related DNA even 
when this is present in a very low amount. Further improvements of this protocol, like real-time PCR (RT-PCR), allow to further improve the detection sensitivity compared with PCR. Thus, RT-PCR represents the most sensitive method to detect pathogen infections within CNS based on CSF samples.

PCR-based protocols have been included in a number of guidelines for the management of patients with CNS infectious diseases. For instance, PCR approaches represent the gold standard to detect meningitis, encephalitis caused by a variety of viruses, HSV encephalitis, HV and JC in CSF (Read et al.,1997; Mamoojee and Chadwick, 2011) and viruses in brain biopsies for the diagnosis of progressive multifocal leukoencephalopathy (Lindquist et al., 1988; Webet et al., 1994; Lakeman and Whitley 1995; Read et al.,1997; Tang et al., 1999; Boivin, 2004; Mamoojee and Chadwick, 2011).

Although for certain tests PCR is currently more costeffective than previous diagnostic tools, the average cost of a PCR-based test is considered quite expensive when compared with microbiological approaches (Lakeman and Whitley, 1995). This limit can be overcome considering that PCR allows a quick and sensitive diagnosis, which reduces hospitalization and the bias of wrong diagnosis with mistreatment costs (Fredricks and Relman, 1999; Chadwick and Lever, 2002).

The goal of this paper is to set-up a qualitative, fast, cheap and reliable molecular approach to detect a range of neurotropic viruses potentially involved in neurological and neuropsychiatric disorders such as HSV I/II, EBV, CMV, VZV, RUBV as well as Toxoplasma gondii (TGR) in CSF samples from patients with suspected infectious CNS diseases, where the pathogen DNA or RNA may be present in a very low amount.

\section{Materials and Methods}

Clinical specimens. In the time interval 2012-2015 at Neuromed Institute of Pozzilli, Isernia, Italy, we collected 100 CSF from patients admitted to the hospital with signs and symptoms of likely, possible or unlikely CNS infection according to the criteria by Jeffery et al. (1997), which were modified ad-hoc considering the kind of patients routinely admitted at Neuromed Institute (patients with recent neurosurgery and fever, patients with known neurological disorder and worsening of mental status etc). In addition, we obtained other tissues (blood, broncho alveolar lavage, and sputum) from patients affected by neurological disorders with a recent history of infection to rule out the bias of any ongoing extracranial infection. Moreover, we tested 50 CSF from patients without any infection. A written informed consent was obtained from each patient.

We considered the presence of a CNS infection as likely when one of the two following conditions was present: i) any rise of white cell count within CSF accompanied by one or more of the following: meningism, headache of fever $\left(\geq 37.5^{\circ} \mathrm{C}\right)$ with no other explanation; ii) onset of altered consciousness or focal neurological signs accompanied by fever $\left(\geq 37.5^{\circ} \mathrm{C}\right)$ or headache with no other explanation. A CNS infection was considered as possible in the presence of a combination of various signs and symptoms. A CNS viral infection was considered unlikely in the following conditions: i) the concomitancy of a specific neurological diagnosis (for example, multiple sclerosis or bacterial meningitis); ii) the absence of specific neurological symptoms (for example, fever of unknown cause, fever in recent neurosurgery and worsening of mental status in already known neurological disorder in the absence of signs of CNS infections). A CSF specimen was defined as abnormal if any of the following was present: white blood cell count (WCC) $>5$ cells/ $\mathrm{mm}^{3}$, protein level $>0.5 \mathrm{~g} / \mathrm{l}$; CSF glucose $<2.2$ or CSF:serum glucose ratio $<0.4$. Clinical data were collected from all enrolled patients. Demographics, clinical, radiological and laboratory data were collected and CSF examinations were correlated with the PCR results. We considered separately immunosuppressed patients, including the following: HIV seropositive, patients receiving chemotherapy, transplants recipient or other immunodeficiency.

Selection of the genomic regions. According to literature data, the most conserved and well-known DNA and cDNA regions for each pathogen were selected. These genomic regions include: i) 35-fold repeated B1 gene for TGR (Burg et al., 1989; RobertGangneux et al., 1999; Sterkers et al., 2012; Teixeira et al., 2013), ii) UL23 gene of the thymidine kinase that catalyses a necessary phosphorylation step of acyclovir for HSV I/II (Van der Beek et al., 2013), iii) conserved regions of EBV genome encoding capsid protein gp220 (Adldinger et al., 1985; Telenti et al., 1990), iv) glycoprotein E for VZV (Cooray et al., 2006; Grahn et al., 2011; Thomsson et al., 2011) v) the variable region within the E1 gene for RUBV (Cooray et al., 2006). As far as the detection of CMV is concerned, a variety of amplification targets so far have been used based upon the immediate-early region (IEA1) (Jiwa et al., 1989; Gerna et al., 1991; Nyberg et al., 1994; Espt et al., 1995). This region of the CMV genome has been shown to possess sporadic sequence variation among clinical strains, and primer mismatching has been shown to reduce the amplification efficiencies of PCR assays (Chou, 1992). To avoid this, U8, another well-characterized region coding for membrane proteins of CMV was selected. The selected regions for each pathogen were considered for the design of primer pairs suitable for PCR applications (Table 1). Primers have been improved for PCR, not considering nested PCR approaches characterized by a higher risk of contamination and decreased sensitivity (Rozenberg and Lebon, 1991; Johnson et al., 2000).

RNA extraction and reverse transcription PCR. For rubella analysis, total RNA was isolated from CSF using TRIzol Reagent (Invitrogen, Life Technologies) according to the manufacturer's instructions. The concentration and purity of RNA samples were 
Table 1. Primers used for PCR and RT-PCR

\begin{tabular}{|c|c|c|c|c|}
\hline Primer & Sequence & PCR band size & Gene & Acc. No. \\
\hline TGR-FW & 5'-TGA AGA GAG GAA ACA GGT GGT CG-3' & $131 \mathrm{bp}$ & $\mathrm{B} 1$ & NW_002234552 \\
\hline TGR-RW & 5'-CCG CCT CCT TCG TCC GTC GTA-3' & & & \\
\hline HSV-I/II-FW & 5'-ATC AAC TTC GAC TGG CCC TTC-3' & $179 \mathrm{bp}$ & UL30 & NP_044632 \\
\hline HSV-I/II-RW & 5'-CCG TAC ATG TCG ATG TTC ACC-3' & & & \\
\hline EBV-FW & 5'-GGC TGG TGT CAC CTG TGT TA-3' & $239 \mathrm{bp}$ & gp220 & NC_007605 \\
\hline EBV-RW & 5'-CCT TAG GAG GAA CAA GTC CC-3' & & & \\
\hline CMV-FW & 5'-GGA TCC GCA TGG CAT TCA CGT ATG T-3' & $408 \mathrm{bp}$ & US7 & NC_006273 \\
\hline CMV-RW & 5'-GAA TTC AGT GGA TAA CCT GCG GCG A-3' & & & \\
\hline VZV-FW & 5'-CAT AAC TCA CCT TAT ATA TGG CC-3' & $677 \mathrm{bp}$ & Glycoprotein E & NC_001348.1 \\
\hline VZV-RW & 5'-AAA AGC TCC AAG TCT CGG TGT-3' & & & \\
\hline RUBV-FW & 5'-CAA CAC GCC GCA CGG ACA AC-3' & $185 \mathrm{bp}$ & E1 & NC_001545 \\
\hline RUBV-RW & 5'-CCA CAA GCC GCG AGC AGT CA-3' & & & \\
\hline$\beta$-Actin-FW & 5'-CAC ACT GTG CCC ATC TAT GAG G-3' & $411 \mathrm{bp}$ & Exon 1 & NM_001101.3 \\
\hline$\beta$-Actin -RW & 5'-GAA GAA ATG AGG GCG GAC TTA G-3' & & & \\
\hline
\end{tabular}

determined using Nanodrop 2000 (Thermo Scientific, Life Technologies). Total RNA (1 $\mu \mathrm{g})$ was reverse transcribed (RT) with SuperScript ${ }^{\circ}$ VILO $^{\mathrm{TM}}$ (Invitrogen, Life Technologies) with Oligo dT primers.

DNA extraction. DNA extraction from CSF and other tissues (blood, broncho alveolar lavage, and sputum) has been performed through the NucleoSpin (MACHEREY-NAGEL GmbH \& Co. $\mathrm{KG})$.

PCR conditions. The PCR was performed using $25 \mu$ DNA (100 ng) or cDNA ( $1 \mu \mathrm{l}$ of reverse transcription), 1x PCR Buffer, $1 \mathrm{mmol} / 1 \mathrm{MgCl}_{2}, 0.2 \mathrm{mmol} / \mathrm{l} \mathrm{dNTPs}, 25 \mathrm{pmol} / \mu \mathrm{l}$ specific forward/ reverse primer, $1.25 \mathrm{U} / \mu \mathrm{l}$ GoTaq Flexi DNA polymerase (Promega, Sunnyvale, CA, USA), using the following cycling conditions: initial denaturation $95^{\circ} \mathrm{C}$ for $3 \mathrm{~min}, 95^{\circ} \mathrm{C}$ for $1 \mathrm{~min}$ and $50 \mathrm{~s}, 62^{\circ} \mathrm{C}$ for $45 \mathrm{~s}$, $72^{\circ} \mathrm{C}$ for $2 \mathrm{~min}$, for 40 cycles, final extension $72^{\circ} \mathrm{C}$ for $10 \mathrm{~min}$ and $4^{\circ} \mathrm{C}$ for $1 \mathrm{~min}$. PCR amplification of each pathogen genome was tested using serial dilution of positive controls ranging from $10^{4}$ to 10 copies (AB Analitica S.r.l.).

PCR detection. PCR products were detected by agarose gel electrophoresis using 2\% agarose gel in $1 \mathrm{x}$ TBE buffer.

Qualitative real-time PCR (RT-PCR). PCR primers were applied to RT-PCR with $\mathrm{SYBR}^{\star}$ Green Master Mix (Invitrogen Life Technologies, Carlsbad, CA) (Watzinger et al., 2004). RT-PCR amplification was performed using $50 \mathrm{ng} / \mu \mathrm{l}$ DNA or cDNA in a $25 \mu \mathrm{l}$ of reaction with $300 \mathrm{nmol} / \mathrm{l}$ of forward and reverse primer specific for each pathogen (Table 1). The reaction mixtures were amplified using the following thermal cycling conditions: an early denaturation and polymerase activation step for $10 \mathrm{~min}$ at $95^{\circ} \mathrm{C}$ followed by 40 cycles of $95^{\circ} \mathrm{C}$ for $45 \mathrm{~s}$ and $62^{\circ} \mathrm{C}$ for $60 \mathrm{~s}$. Amplification and detection were performed on a CFX Connect ${ }^{\mathrm{TM}}$ Real Time System (Bio-Rad Life Science, CA) and Rotor-Gene ${ }^{\mathrm{TM}} 3000$ (Corbett Research, Qiagen). For each sample $\beta$-actin was amplified to confirm the efficiency of DNA extraction.
The cycle threshold $(\mathrm{Ct})$ values from unknown samples were plotted on these standard curves and the ratio of the number of virus genome per cell was calculated. Curves were generated by the Sequence Detection System software, plotting Ct against the number of viral genome copies. Run acceptability was defined as a correlation coefficient (R2) $>0.98$ and a slope between -3.6 and -3.1 , corresponding to reaction efficiencies between 90 and $110 \%$, according to the equation: Efficiency $=10(-1 /$ slope $)-1$ (Yuan et al., 2006).

\section{Results}

In this work we designed and implemented a PCRbased approach for qualitative detection of six neurotropic pathogens (HSV I/II, EBV, CMV, VZV, RUBV and TGR). According to the literature the most conserved and wellknown DNA and cDNA regions for each pathogen were selected, and primers pairs suitable for PCR applications were designed (Table 1). Each PCR product was tested using as positive controls six commercially available genomic DNA (HSV I/II, EBV, CMV, VZV and TGR) or cDNA (RUBV), in four different dilutions ranging from $10^{4}$ to 10 copies (Fig. 1).

As shown in Fig. 1a, PCR on 2\% agarose gel was able to detect each pathogen in a concentration of $10^{4}, 10^{3}$ and $10^{2}$ copies $/ \mathrm{ml}$, but could not detect lower concentrations (10 copies/ml).

To improve the detection below $10^{2}$ copies $/ \mathrm{ml}$, the same set of primers and positive controls were evaluated in RT-PCR application using SYBR green (Fig. 1b). RT-PCR application strongly improved the detection rate up to 10 copies/ml for each pathogen. 
(a)

TGR

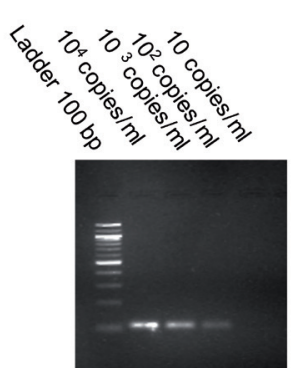

HSV I/I

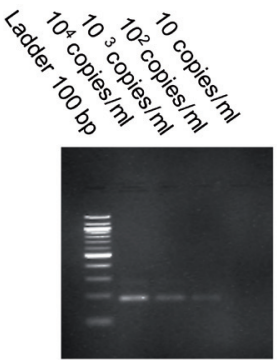

EBV

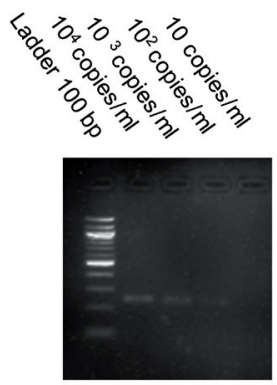

CMV
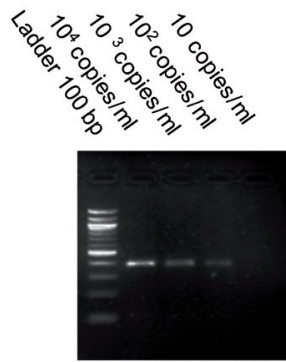

VZV

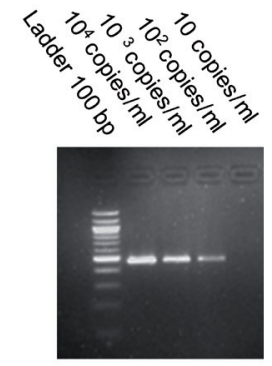

RUBV

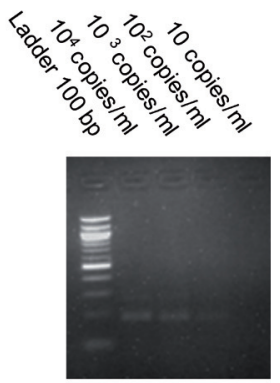

Then, the PCR-based protocols (PCR and RT-PCR) were evaluated in $100 \mathrm{CSF}$ from patients admitted to the hospital with signs and symptoms of likely, possible or unlikely CNS infection, as reported in materials and methods.

PCR detected 17 positive samples ( 1 for TGR, 1 for HSVI/II, 6 for EBV, 7 for CMV, 1 for VZV and 1 for RUBV), while RT-PCR detected 22 positive samples ( 1 for TGR, 1 for HSVI/II, 8 for EBV, 10 for CMV, 1 for VZV and 1 for RUBV). The application of RT-PCR protocol improved the detection rate of 5 out of 100 patients ( 2 positive samples for EBV and 3 positive samples for CMV). In support of this, in Fig. 2 are shown molecular analyses for EBV (Fig. 2a) and CMV (Fig. 2b) respectively, in CSF from two different patients who were diagnosed as negative by PCR on agarose gel and positive by RT-PCR approach.

The same PCR-based protocols (PCR and RT-PCR) were evaluated in 50 CSF from patients without CNS infection, and no healthy positive subjects and false-positive were detected.

The possibility to detect up to 10 copies/ml allows to improve the detection rate of this protocol, suitable for the identification of HV in CSF from neurological patients.

\section{Fig. 1}

PCR products obtained from serial dilutions of positive control In this figure are shown PCR products obtained from serial dilutions $\left(10^{4}\right.$ $\left.10^{3}, 10^{2}, 10\right)$ of positive controls for TGR, HSVI/II, EBV, CMV, VZV and RUBV detected in PCR separated on $2 \%$ agarose gel (a) and detected by RT-PCR (b).

(b) TGR

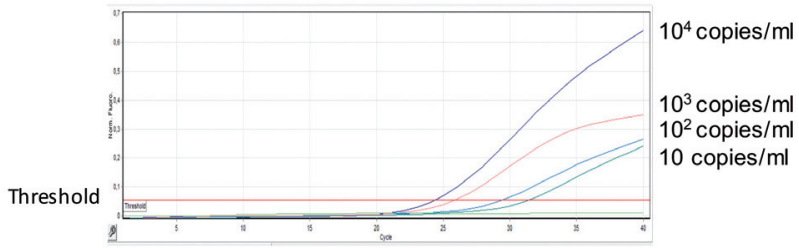

HSV I/II

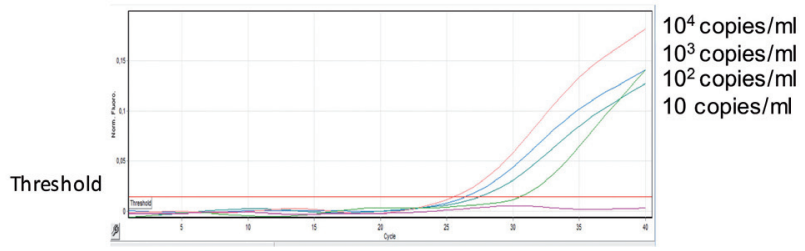

EBV

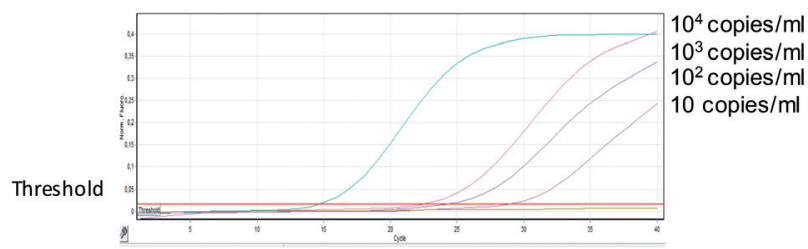

\section{CMV}

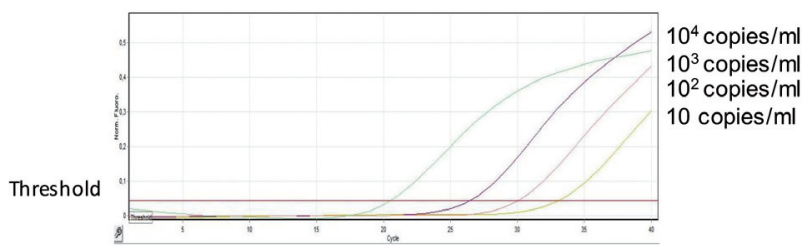

VZV

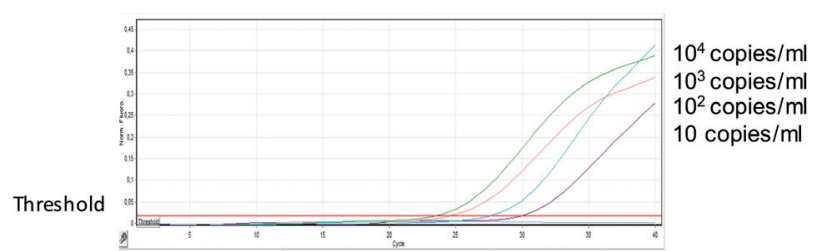

RUBV

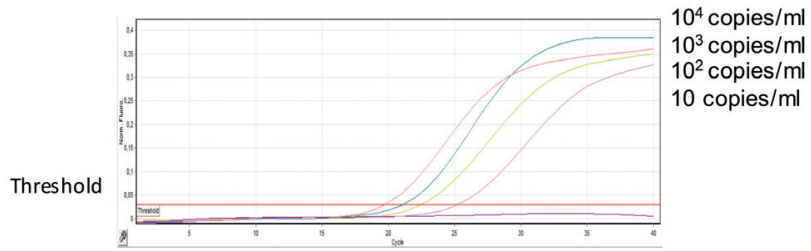


(a)

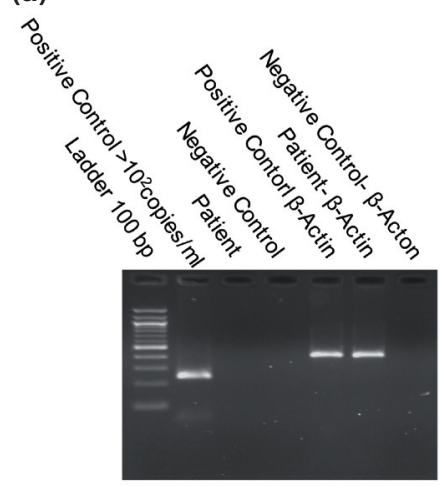

(b)
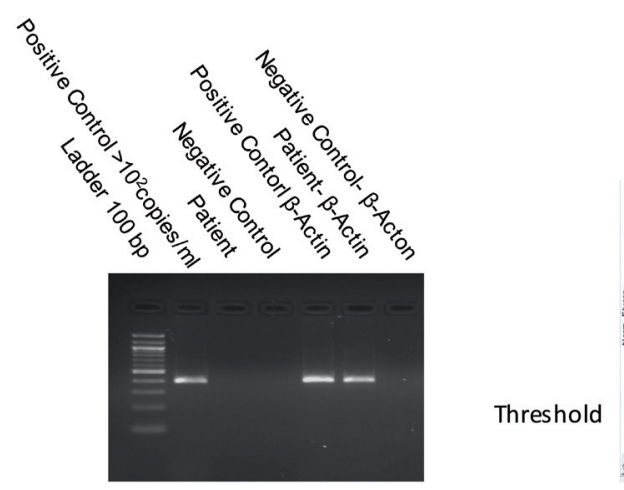

Threshold

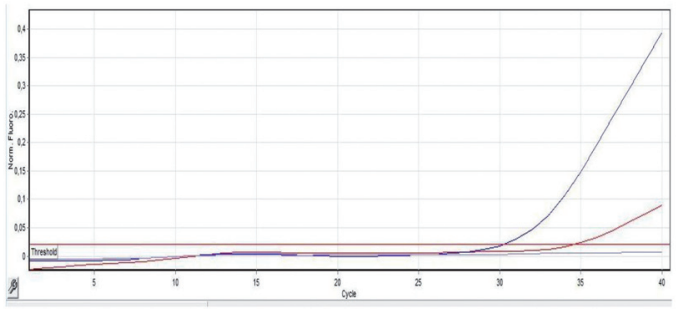

Positive Control $>10^{2}$ copies $/ \mathrm{m}$

Patient

Negative Control

Fig. 2
Positive Control $>10^{2}$ copies $/ \mathrm{ml}$

Patient

Negative Control

PCR (left) and RT-PCR (right) analysis for EBV (a) and CMV (b) respectively, in CSF from two different patients On the left side are shown PCR product separated on 2\% agarose gel for EBV (A) and CMV (B). Lane 1: molecular weight standard (100 bp DNA Ladder); Lane 2: positive control with $>10^{2}$ copies/ml viremia; Lane 3: patient analysed; Lane 4: PCR negative control; Lane 5: positive control for $\beta$-actin; Lane 6: patient for $\beta$-actin; Lane 7: PCR negative control for $\beta$-actin. On the right side are shown RT-PCR plots for EBV (A) and CMV (B). Amplification curves: i) positive control with $>10^{2}$ copies/ml viremia; ii) patient analysed; iii) negative control.

\section{Discussion}

Detection of HV in CSF is quite complex since these pathogens are often present in very few copies. The PCR is a powerful molecular approach that is increasingly applied to the diagnosis of infectious diseases. This technique is based on the amplification of specific nucleic acid sequences of DNA or cDNA, and this allows to detect a pathogen genome in CSF also when it is present in low copy numbers.

Thus, PCR represents a unique approach for the molecular diagnosis of CSF in CNS infection. All PCR-based assays detect pathogen nucleic acid in clinical samples and do not require growth of the organisms, and this offers the possibility of a quick, sensitive, and specific diagnostic approach. In the clinical routine of the Neurological Institute, this approach is fundamental to prioritize the optimal therapeutic treatment and to reach a fast and reliable diagnosis.
For example, a large amount of patients are admitted for fever after a recent history of neurosurgery or fever, which occurs during worsening of mental status in concomitancy with a neurological disorder. In these cases, PCR detection of pathogen DNA is an important tool to confirm/exclude an empirical antimicrobial treatment and to adopt reliable examinations to assess the specificity of otherwise general neurological symptoms.

Unfortunately, molecular identification of pathogen DNA in CSF during neurological disorder is not well defined yet. This is the case of CMV DNA that is frequently detected in the CSF of patients during acute neurological disorders. Different studies show a strong association between CMV virus in CSF and Guillain-Barrè Syndrome (GBS) (Steininger et al., 2004), where the re-activation of a persistent CMV infection during the course of GBS in the CNS is likely to represent the causal mechanism. Moreover, CMV was found 
by PCR in $8 \%$ of post-mortem brain samples from patients without neurological disorders, to underline the specific ability of CMV to cross the blood-brain barrier (BBB) and remaining latent in the CNS after a primary infection (Sanders et al., 1996).

We developed PCR-based protocols that were evaluated in 100 CSF from patients admitted to the hospital with signs and symptoms of likely, possible or unlikely CNS infection.

PCR detected 17 positive samples ( 1 for TGR, 1 for HSVI/II, 6 for EBV, 7 for CMV, 1 for VZV and 1 for RUBV), while RT-PCR detected 22 positive samples ( 1 for TGR, 1 for HSV I/II, 8 for EBV, 10 for CMV, 1 for VZV and 1 for RUBV). The application of RT-PCR protocol improved the detection rate of 5 out of 100 patients (2 positive samples for EBV and 3 positive samples for CMV), as shown in the examples.

According to the study of Davies and colleagues (Davies et al., 2005), in our study we observed mostly EBV-positive PCR in patients with unlikely infection rather than HSV and CMV, but the number of specimens associated with the clinical symptoms is still too small to allow any conclusion. Previous data reported high predictive value of EBV PCR detection in HIV- associated lymphoma, but other more recent studies reported lower sensitivity (Cinque et al., 1993; Ivers et al., 2004). EBV-positive PCR results should therefore be interpreted with caution, also considering that in most cases the detection of EBV in CSF occurs in the absence of any CNS involvement.

Thus, EBV detection in CSF might be the result of unusual presentation of a CNS viral infection, as well as an epiphenomenon. EBV might be present in CSF either due to the reactivation of the virus after concurrent stress to the host or it may be due to the latent infection of leukocytes trafficking into the intrathecal space (Davies et al., 2005). For instance, the leukocytes carriage of EBV and CMV has already been described in the synovial fluid and tissue of diseased joints (Stahl et al., 2000).

In summary, although the use of commercial positive control for each genome points out the possibility to detect up to 10 genome copies/ml with RT-PCR, a large scale validation considering several positive and negative CSF is strongly required to establish the actual sensitivity and specificity of this approach. Then, this protocol could be integrated with clinical routine exams for a quick diagnosis and a better patient management.

Acknowledgement. The authors wish to thank the patients enrolled in this research.

\section{References}

Adldinger HK, Delius H, Freese UK, Clarke J, Bornkamm GW (1985): A putative transforming gene of Jijoye virus differs from that of Epstein-Barr virus prototypes. Virol- ogy 141, 221-234. https://doi.org/10.1016/0042-6822(85)90253-3

Boivin G (2004): Diagnosis of herpesvirus infections of the central nervous system. Herpes 11 (Suppl. 2), pp. 48A-56A.

Burg JL, Grover CM, Pouletty P, Boothroyd JC (1989): Direct and sensitive detection of a pathogenic protozoan, Toxoplasma gondii, by poly- merase chain reaction. J. Clin. Microbiol. 27, 1787-1792.

Chadwick DR, Lever AM (2002): Presentation and impact of new diagnostic modalities in the management of meningitis in adults at a teaching hospital: a five year review. QJM: An. Int. J. Med. 95, 663-670. https://doi.org/10.1093/ qimed/95.10.663

Chou S (1992): Effect of interstrain variation on diagnostic DNA amplification of the cytomegalovirus major immediateearly gene region. J. Clin. Microbiol. 30, 2307-2310.

Cinque P, Brytting M, Vago L, Castagna A, Parravicini C, Zanchetta N, D'Arminio Monforte A, Wahren B, Lazzarin A, Linde A (1993): Epstein-Barr virus DNA in cerebrospinal fluid from patients with AIDS-related primary lymphoma of the central nervous system. Lancet 342, 398-401. https:// doi.org/10.1016/0140-6736(93)92814-A

Connelly KP, De Witt LD (1994): Neurologic complications of infectious mononucleosis. Pediatr. Neurol. 10, 181-184. https://doi.org/10.1016/0887-8994(94)90021-3

Cooray S, Warrener L and Jin L (2006): Improved RT-PCR for diagnosis and epidemiological surveillance of rubella. J. Clin. Virol. 35, 73-80. https://doi.org/10.1016/j. jcv.2004.12.020

Davies NW, Brown LJ, Gonde J, Irish D, Robinson RO, Swan AV, Banatvala J, Howard RS, Sharief MK, Muir P (2005): Factors influencing PCR detection of viruses in cerebrospinal fluid of patients with suspected CNS infections. J. Neurol. Neurosurg. Psychiatry 76, 82-87. https://doi.org/10.1136/ jnnp.2004.045336

Fredricks DN, Relman DA (1999): Application of Polymerase Chain Reaction to the Diagnosis of Infectious Diseases. Clin. Infect. Dis. 29, 475-486. https://doi.org/10.1086/598618

Espy MJ, Patel R, Paya CV and Smith TF (1995): Comparison of three methods for the extraction of viral nucleic acids from blood cultures. J. Clin. Microbiol. 33, 41-44.

Gerna G, Zipeto D, Parea M, Revello MG, Silini E, Percivalle E, Zavattoni M, Grossi P, Milanesi G (1991): Monitoring of human cytomegalovirus infections and ganciclovir treatment in heart transplant recipients by determination of viremia, antigenemia and DNAemia. Infect. Dis. 164, 488-498. https://doi.org/10.1093/infdis/164.3.488

Grahn A, Studahl M, Nilsson S, Thomsson E, Bäckström M, Bergström T (2011): Varicella-Zoster Virus (VZV) Glycoprotein E Is a Serological Antigen for Detection of Intrathecal Antibodies to VZV in Central Nervous System Infections, without Cross-Reaction to Herpes Simplex Virus 1. Clin. Vaccine Immunol. 18, 1336-1342. https:// doi.org/10.1128/CVI.05061-11

Ivers LC, Kim AY and Sax PE (2004): Predictive value of polymerase chain reaction of cerebrospinal fluid for detection of Epstein-Barr virus to establish the diagnosis of HIV-related 
primary central nervous system lymphoma. Clin. Infect. Dis. 38, 1629-1632. https://doi.org/10.1086/420934

Jeffery KJ1, Read SJ, Peto TE, Mayon-White RT, Bangham CR (1997): Diagnosis of viral infections of the central nervous system: clinical interpretation of PCR results. Lancet 349, 313-317. https://doi.org/10.1016/S0140$\underline{6736(96) 08107-X}$

Jiwa NM, Van Gemert GW, Raap AK, Van de Rijke FM, Mulder A, Lens PF, Salimans MM, Zwaan FE, Van Dorp W, Van der Ploeg M. (1989): Rapid detection of human cytomegalovirus DNA in peripheral blood leukocytes of viremic transplant recipients by the polymerase chain reaction. Transpl. 48, 72-77. https://doi.org/10.1097/00007890198907000-00017

Johnson G, Nelson S, Petric M and Tellier R (2000): Comprehensive PCR-based assay for detection and species identification of human herpesviruses. J. Clin. Microbiol. 38, 3274-3279.

Lakeman FD and Whitley RJ (1995): Diagnosis of herpes simplex encephalitis: application of polymerase chain reaction to cerebrospinal fluid from brain biopsied patients and correlation with disease. National Institute of Allergy and Infectious Diseases Collaborative Antiviral Study Group. J. Infect. Dis. 171, 857-863. https://doi.org/10.1093/infdis/171.4.857

Lindquist L, Linné T, Hansson LO, Kalin M, Axelsson G (1988): Value of cerebrospinal fluid analysis in the differential diagnosis of meningitis: a study in 710 patients with suspected central nervous system infection. Eur. J. Clin. Microbiol. Infect. Dis. 7, 374-380. https://doi. org/10.1007/BF01962340

Mamoojee Y and Chadwick D (2011): How appropriate are cerebrospinal fluid polymerase chain reaction requests for suspected central nervous system infections?. Clin. Med. 11, 554-557. https://doi.org/10.7861/clinmedicine.11-6-554

Nyberg G, Bergström T, Blohmé I, Nordén G, Olofsson S, Ricksten A (1994): Clinical evaluation in organ transplant patients of a polymerase chain reaction test for CMV DNA applied on white blood cells and serum. Transpl. Int. 7, 428-433. https://doi.org/10.1111/j.1432-2277.1994.tb01262.x

Read, SJ, Jeffery KJM, Bangham CRM (1997): Aseptic meningitis and encephalitis: the role of PCR in the diagnostic laboratory. J. Clin. Microbiol. 35, 691-696.

Robert-Gangneux F, Gavinet MF, Ancelle T, Raymond J, TourteSchaefer C, Dupouy-Camet J (1999) : Value of prenatal diagnosis and early postnatal diagnosis of congenital toxoplasmosis: retrospective study of 110 cases. J. Clin. Microbiol. 37, 2893-2898.

Rozenberg F and Lebon P (1991): Amplification and characterization of herpesvirus DNA in cerebrospinal fluid from patients with acute encephalitis. J. Clin. Microbiol. 29, 2412-2417.

Sanders VJ, Felisan S, Waddell A and Tourtellotte WW (1996): Detection of herpesviridae in postmortem multiple sclerosis brain tissue and controls by polymerase chain reaction. J. Neurovirol. 2, 249-258. https://doi. org/10.3109/13550289609146888
Stahl HD, Hubner B, Seidl B, Liebert UG, van der Heijden IM, Wilbrink B, Kraan MC, Emmrich F, Tak PP (2000): Detection of multiple viral DNA species in synovial tissue and fluid of patients with early arthritis. Ann. Rheum. Dis. 59, 342-346. https://doi.org/10.1136/ard.59.5.342

Steininger C, Popow-Kraupp T, Seiser A, Gueler N, Stanek G, Puchhammer E (2004): Presence of Cytomegalovirus in Cerebrospinal Fluid of Patients with Guillain-Barre' Syndrome. J. Infect. Dis. 189, 984-989. https://doi. org/10.1086/382192

Sterkers Y, Pratlong F, Albaba S, Loubersac J, Picot MC, Pretet V, Issert E, Boulot P, Bastien P. (2012): Novel interpretation of molecular diagnosis of congenital toxoplasmosis according to gestational age at the time of maternal infection. J. Clin. Microbiol. 50, 3944-3951. https://doi.org/10.1128/ LCM.00918-12

Tang YW, Hibbs JR, Tau KR, Qian Q, Skarhus HA, Smith TF, Persing DH (1999): Effective use of polymerase chain reaction for diagnosis of central nervous system infections. Clin. Infect. Dis.29, 803-806. https://doi. org/10.1086/520439

Teixeira LE, Kanunfre KA, Shimokawa PT, Targa LS, Rodrigues JC, Domingues W, Yamamoto L, Okay TS (2013): The performance of four molecular methods for the laboratory diagnosis of congenital toxoplas-mosis in amniotic fluid samples. Rev. Soc. Bras. Med. Trop. 46, 584-588. https:// doi.org/10.1590/0037-8682-0095-2013

Telenti A, Marshall WF and Smith TF (1990): Detection of EpsteinBarr virus by polymerase chain reaction. J. Clin. Microbiol. 28, 2187-2190.

Thomsson E, Persson L, Grahn A, Snäll J, Ekblad M, Brunhage E, Svensson F, Jern C, Hansson GC, Bäckström M, Bergström T (2011): Recombinant glycoprotein E produced in mammalian cells in large-scale as an antigen for varicellazoster-virus serology. J. Virol. Methods 175, 53-59. https://doi.org/10.1016/j.jviromet.2011.04.014

Van der Beek MT, Claas EC, van der Blij-de Brouwer CS, Morfin F, Rusman LG, Kroes AC, Vossen AC (2013) Rapid susceptibility testing for herpes simplex virus type 1 using real-time PCR. J. Clin. Virol. 56, 19-24. https://doi. org/10.1016/j.jcv.2012.09.004

Watzinger F, Suda M, Preuner S, Baumgartinger R, Ebner K, Baskova L, Niesters HG, Lawitschka A, Lion T (2004): Real-time quantitative PCR assays for detection and monitoring of pathogenic human viruses in immunosuppressed pediatric patients. J. Clin. Microbiol. 42, 5189-5198. https:// doi.org/10.1128/JCM.42.11.5189-5198.2004

Weber T, Turner RW, Frye S, Ruf B, Haas J, Schielke E, Pohle HD, Lüke W, Lüer W, Felgenhauer K, G Hunsmann (1994): Specific diagnosis of progressive multifocal leucoencephalopathy by polymerase chain reaction. J. Infect. Dis. 169, 1138-1141. https://doi.org/10.1093/ infdis/169.5.1138

Yuan JS, Reed A, Chen F, Stewart CN Jr (2006): Statistical analysis of real-time PCR data. BMC Bioinformatics 7, 85. https:// doi.org/10.1186/1471-2105-7-85 